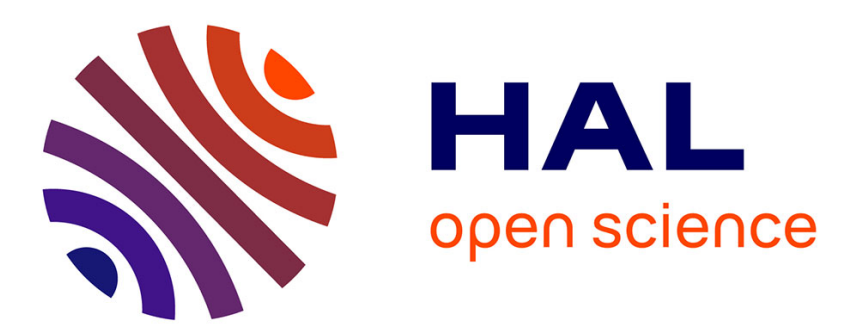

\title{
Titanium carbide and titanium carbonitride obtained by chemical vapor deposition from orgranometallic precursor in the range $450-800^{\circ} \mathrm{C}$
}

\author{
J. Slifirski, F. Teyssandier
}

\section{- To cite this version:}

J. Slifirski, F. Teyssandier. Titanium carbide and titanium carbonitride obtained by chemical vapor deposition from orgranometallic precursor in the range $450-800^{\circ} \mathrm{C}$. Journal de Physique IV Proceedings, 1993, 03 (C3), pp.C3-367-C3-374. 10.1051/jp4:1993350 . jpa-00251407

\section{HAL Id: jpa-00251407 https://hal.science/jpa-00251407}

Submitted on 1 Jan 1993

HAL is a multi-disciplinary open access archive for the deposit and dissemination of scientific research documents, whether they are published or not. The documents may come from teaching and research institutions in France or abroad, or from public or private research centers.
L'archive ouverte pluridisciplinaire HAL, est destinée au dépôt et à la diffusion de documents scientifiques de niveau recherche, publiés ou non, émanant des établissements d'enseignement et de recherche français ou étrangers, des laboratoires publics ou privés. 


\title{
Titanium carbide and titanium carbonitride obtained by chemical vapor deposition from organometallic precursor in the range 450-800 ${ }^{\circ} \mathrm{C}$
}

\section{J. SLIFIRSKI and F. TEYSSANDIER*}

Etablissement Technique Central de l'Armement, 16 bis avenue Prieur de la Côte d'Or, 94114 Arcueil cedex, France

${ }^{*}$ Institut de Science et de Génie des Matériaux et Procédés, Université de Perpignan, 52 avenue de Villeneuve, 66860 Perpignan cedex, France

\begin{abstract}
Titanium carbide coatings have been deposited on steel in a cold wall reactor from titanocene dichloride vaporized in a hydrogen carrier gas. Titanium carbonitride was obtained in the same experimental device by addition of ammonia in the gas phase. These materials were deposited at atmospheric pressure in the temperature range $450-800{ }^{\circ} \mathrm{C}$ with appreciable deposition rates. According to the temperature range of vaporization of the solid precursor, the deposition proceeded from the gaseous species coming either from the direct sublimation of the initial molecule or from a vaporization of by-products resulting from its decomposition in the vaporization crucible. These two basic vaporization processes resulted in coatings of different compositions and properties. Several characterizations such as thickness of the deposit, surface morphology, composition, grain size, hardness and adherence were carried out.
\end{abstract}

\section{1-Introduction}

Titanium based compounds such as $\mathrm{TiC}, \mathrm{TiN}$ and $\mathrm{TiC}_{\mathrm{X}} \mathrm{N}_{\mathrm{y}}$ are widely used as protective coatings for tribological applications. The conventional CVD industrial process with $\mathrm{TiCl}_{4}+\mathrm{H}_{2}+\mathrm{CH}_{4}$ and/or $\mathrm{NH}_{3}$ dopant mixture requires a minimum substrate temperature of $950^{\circ} \mathrm{C}$ for $\mathrm{TiC}$ [1] $\left(500^{\circ} \mathrm{C}\right.$ for TiN [2]). Such a high temperature is not suitable for the coating of steel substrates and can be substantially lowered by the use of less stable precursors such as organometallic compounds. This route applied to titanium carbides or nitrides have already been investigated by several authors [3-10]. It generally leads to very low deposition rates $(<2 \mu \mathrm{m} / 6 \mathrm{~h})$ and requires excessive experimental care due to the high reactivity of these organometallic compounds to moisture and/or oxygen. Thereby, we intended to find a precursor not too reactive that allows the deposition of TiC and TiN at low temperature and at atmospheric pressure.

For that purpose, a rather stable solid compound: titanocene dichloride $\mathrm{Cp}_{2} \mathrm{TiCl}_{2}$ $\left(\mathrm{Cp}=\pi-\mathrm{C}_{5} \mathrm{H}_{5}\right)$ was selected. The objective of this paper is to look at the relationships between the coating parameters and some properties of the deposits. In a previous paper [13], we focused on the thermal behavior of $\mathrm{Cp}_{2} \mathrm{TiCl}_{2}$ and three characteristic temperatures were determined. The influence of both the vaporization and substrate temperatures on the main features of the deposits were investigated. The surface morphologies were observed by scanning electron microscope (SEM) equipped with an 
energy dispersive X-ray spectrometer (EDS). The elemental chemical composition of the deposits was measured by electron probe microanalysis with dispersive wavelength (EPMA-WDS). Preliminary studies leading to TiN deposits with addition of ammonia in the gas phase are presented.

\section{2-Experimental procedure and characterizations}

Previous manuscripts describe the CVD apparatus as well as the experimental procedure and we only review the principles here [12-13]. All the experiments were carried out in a cold wall reactor at atmospheric pressure under hydrogen flow. The steel substrates (9335) machined in a rod of diameter $16 \mathrm{~mm}$ were $5 \mathrm{~mm}$ thick. For the titanium nitride deposits, ammonia was delivered by a mass flowmeter and mixed with the hydrogen carrier gas before entering the reactor. The organometallic precursor handling system consisted of a cylinder shaped steel crucible heated by a resistor (Thermocoax) tightly wrapped around the whole lateral surface and regulated by a PID controller. In order to prevent extra heating of the organometallic compound from the radiating substrate located above, the crucible was covered by a lid with a hole $($ diam. $=1 \mathrm{~mm})$ drilled in the middle.

The thickness of the deposits was determined by abrasion through the coating, obtained by the rotation of a stainless steel ball (diam. $15 \mathrm{~mm}$ ) together with an abrasive agent (diamond 1 or $3 \mu \mathrm{m}$ ). The thickness value was calculated from the diameters of the ring prints measured by optical microscopy. The $\mathrm{X}$-ray diffraction patterns were recorded on a Philips PW 1729 diffractometer equipped with a cobalt anticathode (wavelength $1.7902 \AA$ ). . Microhardness and dynamic indentation testing were also investigated. Vickers microhardness was measured on a Shimadzu type $M$ tester. Five indentations for each load with a dwell time of $15 \mathrm{~s}$ were made on the metallographic preparation of the surface of the coatings. The microhardness measurements were made up to the maximum load available without occurrence of cracks around the Vickers print. For each measurement, both the standard Vickers value under $50 \mathrm{~g}$ load and the hardness corrected according to the method proposed by Farges and Degout [14] are given. In the latter case the following empirical relationship allows the determination of $\mathrm{H}_{\infty}$ that is not dependent on the applied load: $\mathrm{H}_{\mathrm{V}}=\mathrm{H}_{\infty}+\beta \mathrm{d}^{-1}$ (d is the diagonal of the indentation print). An "intrinsic" hardness $\left(\mathrm{H}_{\infty}\right)$ is thus deduced from the extrapolation at infinite load of the linear regression applied to the data when plotting $\mathrm{H}_{\mathrm{V}}$ against 1/d. The correlation coefficient of the linear regression allows to check that no heterogeneity (influence of substrate) is taken into account in the measurement.

Adhesive strength measurements of the coating on the steel substrate were also determined on a CSEM scratch tester equipped with an acoustic emission detector. The critical load Lc which is the minimum load at which damage by lack of adherence can be observed (scratching speed $=10 \mathrm{~mm} \cdot \mathrm{min}^{-1}$ ) is thus determined. Lc is often used to provide an estimate of the adherence between the coating and the substrate but depends not only on the adherence but also on several intrinsic (diamond tip radius, scratching speed) and extrinsic (substrate hardness, coating thickness) factors. It is nevertheless suitable for the comparison of the adherence of similar coatings.

\section{3-Results and discussion}

\section{3-1-Influence of the vaporization temperature of the precursor Tp}

The other parameters remaining unchanged (substrate temperature $\mathrm{Ts}=740^{\circ} \mathrm{C}$, distance 
between vaporisation crucible and substrate $d=20 \mathrm{~mm}$ and hydrogen flow $=301 . \mathrm{h}^{-1}$ ), three characteristic temperatures were selected in a previous work [13] for the vaporization of $\mathrm{Cp}_{2} \mathrm{TiCl}_{2}: 240^{\circ} \mathrm{C}$ when almost pure sublimation of the precursor takes place, $300^{\circ} \mathrm{C}$ which is just above its decomposition temperature $\left(290^{\circ} \mathrm{C}\right)$ and $360^{\circ} \mathrm{C}$ that allows a rapid vaporization of the by-products of the decomposed solid precursor. The first characterizations revealed two basic types of layers both of which included a high carbon content (60 at\%) as expected from the composition of the initial molecule $(\mathrm{C} / \mathrm{Ti}=10)$. The main difference between the two types of layers lied in fact in the percentages of oxygen and chlorine which were dependent on the vaporization temperature:

- At $240^{\circ} \mathrm{C}$, the deposit presented a high oxygen content and the following typical composition was measured: $\mathrm{Ti}_{0.39} \mathrm{C}_{0.43} \mathrm{O}_{0.175} \mathrm{Cl}_{0.005}$

- At 300 as well as at $360^{\circ} \mathrm{C}$, two different layers were successively deposited. The first layer $(<2 \mu \mathrm{m})$ adjacent to the substrate had a composition identical to that obtained at $240^{\circ} \mathrm{C}$. The upper one, thicker, had a far lower oxygen content but a slightly higher chlorine content: $\mathrm{Ti}_{0.41} \mathrm{C}_{0.55} \mathrm{O}_{0.02} \mathrm{Cl}_{0.02}$.

Though chemical analysis of the amount of oxygen present in the precursor was not possible because of the presence of titanium, oxygen (or moisture) was assumed to come from the precursor. The sublimation and further transport of the precursor favored the gettering of oxygen in the deposit. In contrast, the decomposition of the molecule in the vaporization crucible followed by the transport of the by-products, allowed the release of oxygen from the precursor, but trapped more chlorine in the deposit.

When $\mathrm{Tp}=240^{\circ} \mathrm{C}$, the thickness of the coatings increased linearly as a function of the deposition time at a rate of $4 \mu \mathrm{m} \cdot \mathrm{h}^{-1}$ (figure 1) (the deposition time started as soon as Tp was reached). This result confirms the preponderance of the sublimation contribution in the vaporization process at $240^{\circ} \mathrm{C}$. The deposition takes place at a constant rate as long as some precursor remains in the vaporization crucible. For $\mathrm{Tp}=300$ or $360^{\circ} \mathrm{C}$ (figure 1), the deposition rate decreased with time and a maximum thickness of $10 \mu \mathrm{m}$ and $16 \mu \mathrm{m}$ were respectively obtained corresponding to the total decomposition of the precursor in the crucible.

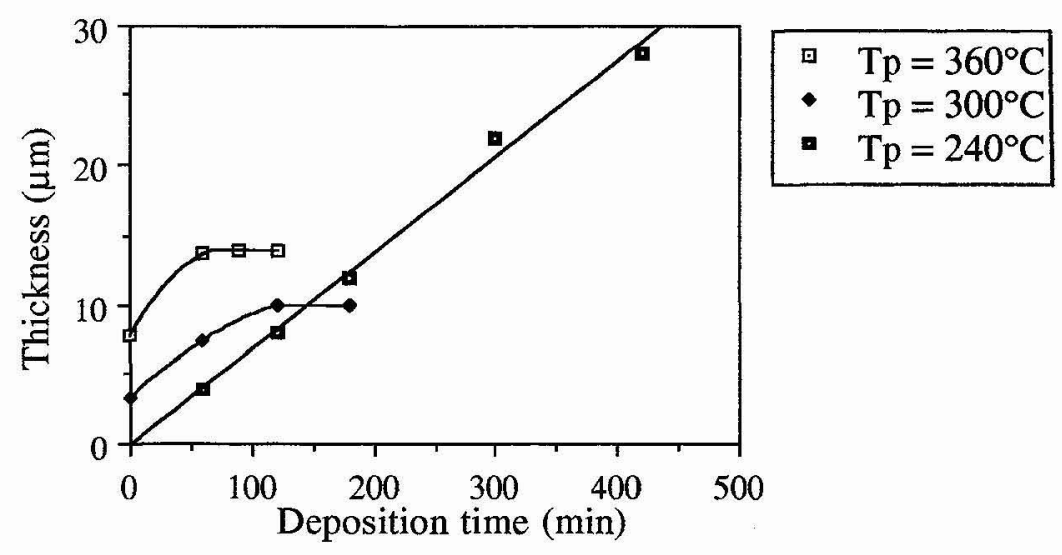

Figure 1: Variations of the thicknesses of the deposits as a function of both the deposition time and the vaporization temperature of the precursor.

The surface morphology observed by SEM was the same in all cases and presented a domed appearance. 
The Vickers microhardness of the coatings ( $\mathrm{HV} 0.05$ ) obtained at $\mathrm{Tp}=240^{\circ} \mathrm{C}$ and $360^{\circ} \mathrm{C}$ were respectively $39 \mathrm{GPa}$ (intrinsic hardness $\mathrm{H}_{\infty}=12.8 \mathrm{GPa}$ ) and $30 \mathrm{GPa}$. The measurement was not carried out on the coatings obtained at $\mathrm{Tp}=300^{\circ} \mathrm{C}$ because the lower coating thickness did not allow the respect of the one tenth rule of thumb which prevents the influence of the substrate. These values are in good agreement with the microhardness values found in literature for a titanium carbide deposited at high temperature $(29 \mathrm{GPa})$. The cracks which appeared for loads as low as $50 \mathrm{~g}$ are indicative of the low toughness of the coatings obtained at $\mathrm{Tp}=240^{\circ} \mathrm{C}$.

The scratch test performed on the samples revealed adhesive failures. The SEM observation of the indentation track clearly showed the beginning of the damage, when the critical load as determined by acoustic emission was reached. The flaking of the coating by adhesive failure revealed the substrate as shown by X-ray imagery. The same type of failure was observed for the samples of the three serials. Due to the influence of the thickness of the deposits on the critical load (table 1, figure 2), only coatings of the same thickness are comparable. According to the Lc criterion, the best adhesion was always observed for the deposits obtained at $\mathrm{Tp}=240^{\circ} \mathrm{C}$.

\begin{tabular}{|c|c|c|c|}
\hline Thickness & $\operatorname{Lc}(\mathrm{N})\left(240^{\circ} \mathrm{C}\right)$ & $\operatorname{Lc}(\mathrm{N})\left(300^{\circ} \mathrm{C}\right)$ & $\operatorname{Lc}(\mathrm{N})\left(360^{\circ} \mathrm{C}\right)$ \\
\hline $8 \mu \mathrm{m}$ & 7.2 & 4.8 & 5.8 \\
\hline $10 \mu \mathrm{m}$ & 9.8 & 6.0 & 6.4 \\
\hline
\end{tabular}

Table 1: Variation of the critical load Lc according to the vaporization temperature for two different thicknesses of the deposits.

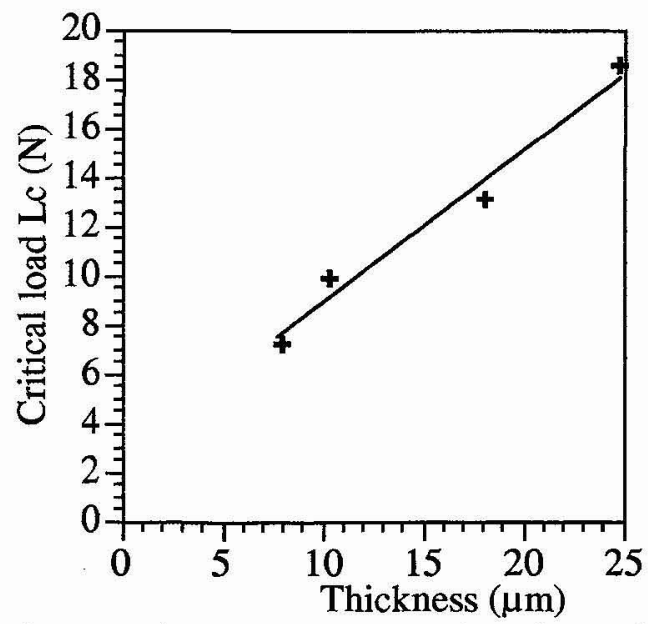

Figure 2: Variation of the critical load as a function of the coating thickness. $\left(\mathrm{Tp}=240^{\circ} \mathrm{C}\right)$

\section{3-2-Influence of the substrate temperature Ts}

In accordance with the above mentioned results, the influence of the substrate temperature was investigated for the three above mentioned vaporization temperatures of the precursor. The thicknesses of the coatings are presented in table 2 as a function of the experimental parameters. 


\begin{tabular}{|c|c|c|c|c|c|}
\hline $\mathrm{Ts}{ }^{\circ} \mathrm{C}$ & $\begin{array}{c}\mathrm{TiC} \\
\mathrm{Tp}=240^{\circ} \mathrm{C}, \\
\mathrm{t}=300 \mathrm{~min}\end{array}$ & $\begin{array}{c}\mathrm{TiC} \\
\mathrm{Tp}=300^{\circ} \mathrm{C}, \\
\mathrm{t}=120 \mathrm{~min}\end{array}$ & $\begin{array}{c}\mathrm{TiC} \\
\mathrm{Tp}=360^{\circ} \mathrm{C}, \\
\mathrm{t}=60 \mathrm{~min}\end{array}$ & $\begin{array}{c}\mathrm{TiN} \\
\mathrm{Tp}=240^{\circ} \mathrm{C}, \\
\mathrm{t}=300 \mathrm{~min}\end{array}$ & $\begin{array}{c}\text { TiN } \\
\mathrm{Tp}=360^{\circ} \mathrm{C}, \\
\mathrm{t}=0 \mathrm{~min}\end{array}$ \\
\hline 800 & 56 & 40 & 44 & & \\
\hline 740 & 22 & 10 & 15 & 25 & 57 \\
\hline 700 & & 3.7 & 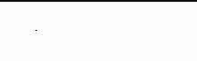 & & \\
\hline 650 & 18 & 2.5 & 6.5 & & \\
\hline 550 & 15 & & 4.5 & 18 & 20 \\
\hline 450 & 7 & & & 6 & 1.5 \\
\hline
\end{tabular}

Table 2: Thicknesses of the coatings $(\mu \mathrm{m})$ as a function of both the substrate temperature (Ts) and the vaporization temperature of the precursor (Tp).

The apparent activation energy deduced from the curves log (thickness) $=f(1 / T)$ plotted in figure 3 is quite comparable at $\mathrm{Tp}=300^{\circ} \mathrm{C}(38 \mathrm{kcal}$.mole -1$)$ to that encountered in literature for high temperature $\mathrm{TiC}$ coatings $[15,16]$. It corresponds to the limitation of the growth rate by the kinetics of the surface reactions. The lower value $(15 \mathrm{kcal} . \mathrm{mole}-1)$ found at $\mathrm{Tp}=360^{\circ} \mathrm{C}$ may be interpreted as the result of a greater influence of the mass transport in the gas phase.
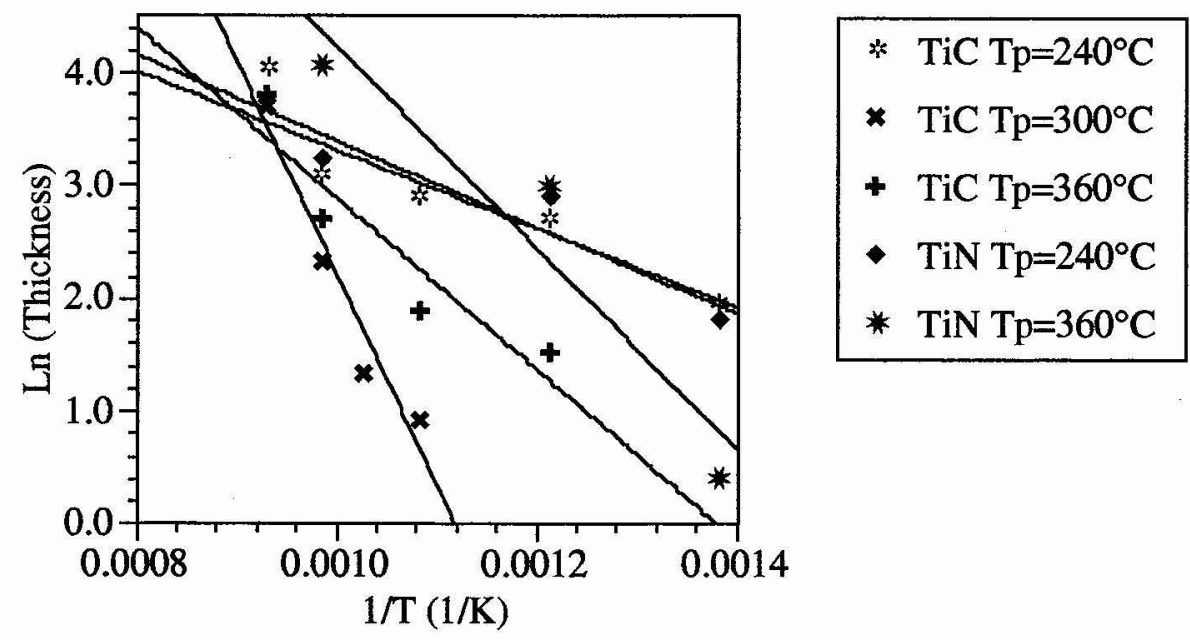

Figure 3: Variations of the apparent activation energies as a function of the vaporization temperature of the precursor (Tp).

In contrast, the $8 \mathrm{kcal} \cdot \mathrm{mole}^{-1}$ value calculated at $\mathrm{Tp}=240^{\circ} \mathrm{C}$ is rather low and even lower if the four thicknesses corresponding to the deposits obtained at the lowest temperatures are considered (6 kcal.mole-1). Values lower than $10 \mathrm{kcal}^{-\mathrm{mole}} \mathrm{e}^{-1}$ are usually attributed to the limitation of the growth rate by mass transport in the gas phase. This situation which is normally encountered at higher temperatures, may arise in our case from the 
sublimation regime of the vaporized precursor. As a matter of fact, if the amount of $\mathrm{Cp}_{2} \mathrm{TiCl}_{2}$ sublimated is lower than the amount consumed by the surface reactions, the thermally activated process measured can correspond to the species diffusion in the gas phase in the vicinity of the substrate.

As already pointed out (paragraph 3.1), the amount of oxygen trapped in the deposits was higher when the precursor was sublimated. Under such conditions $\left(\mathrm{Tp}=240^{\circ} \mathrm{C}\right)$, the amount of oxygen varied also according to the substrate temperature. In the deposition range $450-800^{\circ} \mathrm{C}$ the amount of titanium was almost unchanged in the range 30 to 40 at\%. In contrast, the large variation of the carbon content according to temperature was compensated by the equivalent amount of oxygen (figure 4). All other deposition parameters being the same, a mixture of titanium carbide and carbon was obtained at $800^{\circ} \mathrm{C}$ although almost pure titanium oxide $\left(\mathrm{TiO}_{2}\right)$ was deposited at $450^{\circ} \mathrm{C}$. The $\mathrm{X}$-ray diffraction analysis of the deposits confirmed these results and indicated that the carbon in excess was amorphous even at high temperature. The diffractograms of the coatings at $450^{\circ} \mathrm{C}$ only revealed peaks corresponding to $\mathrm{TiO}_{2}$. The $\mathrm{TiC}$ peaks were only detected on the diffractograms of films deposited above $550^{\circ} \mathrm{C}$.
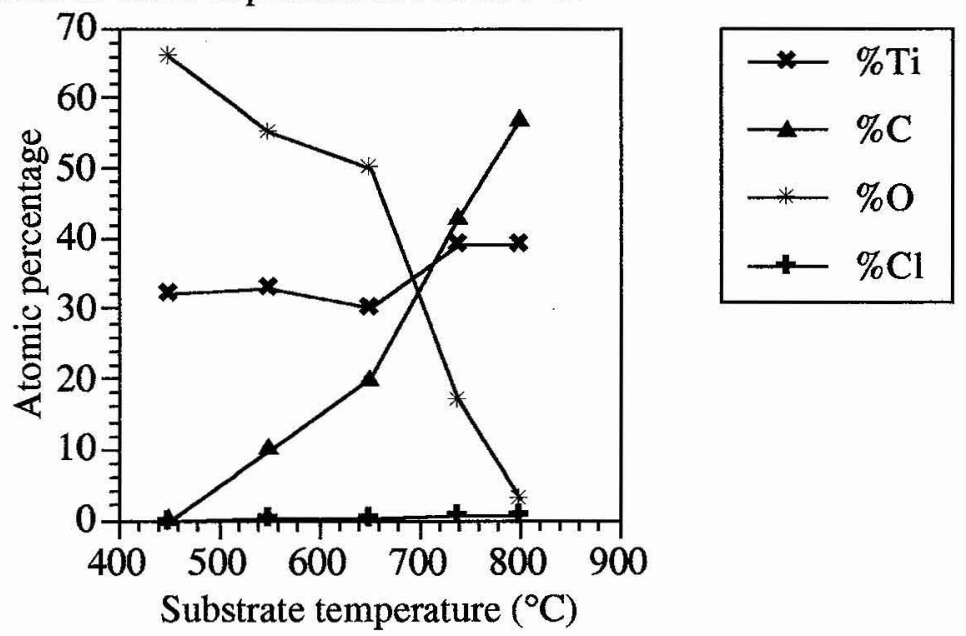

Substrate temperature $\left({ }^{\circ} \mathrm{C}\right)$

Figure 4: Composition of the deposits measured by EPMA-WDS and plotted as a function of substrate temperature $\left(\mathrm{Tp}=240^{\circ} \mathrm{C}\right)$.

Four characteristic surface morphologies were observed by SEM (figure 5). At 800 and $740^{\circ} \mathrm{C}$ the surface had the grey metallic aspect of titanium carbide and presented a nodular aspect. At $650^{\circ} \mathrm{C}$, the colour was dark-grey and a cauliflower morphology was observed. At $550^{\circ} \mathrm{C}$, the colour was more light and the surface composed of small apparent grains. At $450^{\circ} \mathrm{C}$, the colour was blue grey and the surface was composed of small crystallites with sharp edges.

Vickers microhardness were only performed on the samples corresponding to $\mathrm{Ts}=550$, 740 and $800^{\circ} \mathrm{C}$. At $450^{\circ} \mathrm{C}$, the coating was not thick enough to prevent the influence of the substrate and at $650^{\circ} \mathrm{C}$, the coating was too dark to see the prints. The microhardness measured at $550^{\circ} \mathrm{C}\left(\mathrm{Hv}_{0.05}=14 \mathrm{GPa}\right)$ was far lower than that measured at 740 and $800^{\circ} \mathrm{C}$ (respectively 39 and $30 \mathrm{GPa}$ ). This value is nevertheless in good accordance with the microhardness of $\mathrm{TiO}_{2}$ mentioned in literature: 7-11 GPa. The scratch test measurements showed that, for a given thickness, the adherence increased when the deposition temperature decreased. 

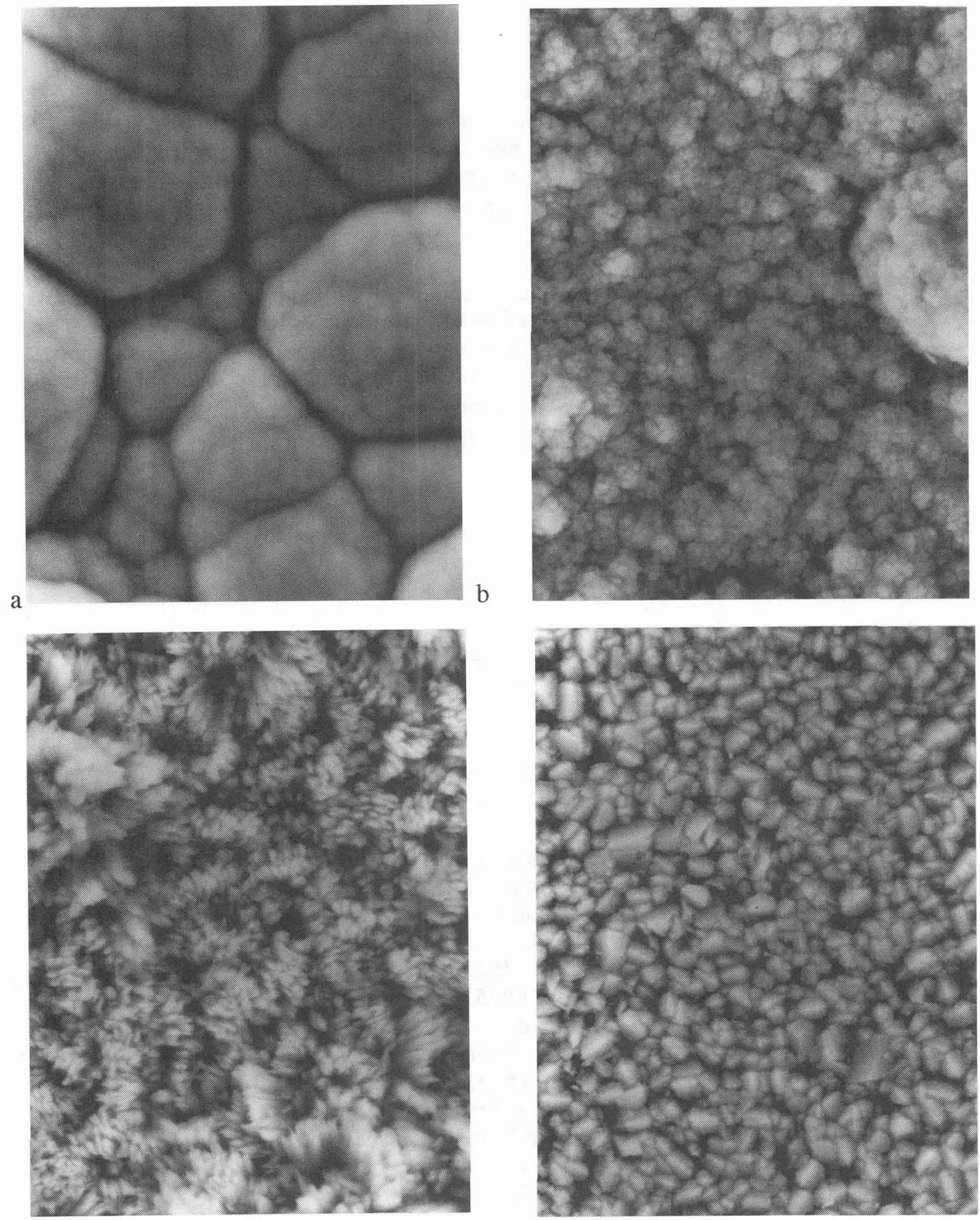
C d

$10 \mu \mathrm{m}$

Figure 5: Surface scanning electron micrographs of the deposits (a) $\mathrm{Ts}=800$ or $740^{\circ} \mathrm{C}$. (b) $\mathrm{Ts}=650^{\circ} \mathrm{C}$. (c) $\mathrm{Ts}=550^{\circ} \mathrm{C}$. (d) $\mathrm{Ts}=450^{\circ} \mathrm{C}$. $\left(\mathrm{TD}=240^{\circ} \mathrm{C}\right.$ ). 


\section{3-3-TiN coatings}

Starting from the experimental parameters leading to $\mathrm{TiC}+\mathrm{C}$ or $\mathrm{TiO}_{2}$ coatings, (distance crucible-substrate $=20 \mathrm{~mm}$, temperature of vaporization of the precursor $=240^{\circ} \mathrm{C}$ and deposition time $=300 \mathrm{~min})$, the addition of ammonia to the gas phase $\left(12.61 . \mathrm{h}^{-1}\right)$ allowed the deposition of titanium nitride. The coatings obtained at 740,550 and $450^{\circ} \mathrm{C}$ had a gold color and presented the X-ray diffraction pattern of titanium nitride TiN (cfc, $\mathrm{a}=4.24 \AA$ ). The thicknesses of the deposits were similar to that obtained without ammonia and almost the same activation energy $\mathrm{Ea}=7 \mathrm{kcal}^{\mathrm{mole}}{ }^{-1}$ was deduced (figure 3). These observations tend to confirm the limitation of the deposition rate at $\mathrm{Tp}=240^{\circ} \mathrm{C}$ by the sublimation rate of the precursor.

Three coatings were also made under the same deposition conditions ( $\mathrm{Ts}=740,550$ and $450^{\circ} \mathrm{C}$ ) but for a temperature of vaporization of the precursor of $360^{\circ} \mathrm{C}$. In contrast with precedent results, the coatings were thicker than the corresponding carbide films (table 2 , figure 3) and the purple color of the deposits, revealed the formation of titanium carbonitride. The activation energy was in this case $\mathrm{Ea}=18 \mathrm{kcal} . \mathrm{mole}^{-1}$ which is quite comparable to the $20 \mathrm{kcal} . \mathrm{mole}^{-1}$ obtained from the conventional set of precursors at higher temperature [17].

\section{Bibliography}

[1] K.G.Stjernberg, H.Gass and H.E.Hintermann, Thin Solid Films 40 (1977) 81.

[2] S.R.Kurtz and R.G.Gordon, Thin Solid Films 140 (1986) 277.

[3] R.M.Fix, R.G.Gordon and D.M.Hoffman, Chem.Mater. 2 (1990) 235.

[4] R.M.Fix, R.G.Gordon and D.M.Hoffman, Mat.Res.Soc.Symp.Proc. 168 (1990) 357.

[5] A.E.Kaloyeros, W.S.Williams, C.M.Alloca, D.B.Pollina and G.S.Girolami, Adv.Ceram.Mater. 2 (1987) 257.

[6] A.E.Kaloyeros, W.S.Williams and G.Constant, Rev.Sci.Instrum. 59 (1988) 1209.

[7] C.M.Alloca, W.S.Williams and A.E.Kaloyeros, J.Electrochem.Soc. 134 (1987) 3170.

[8] R.M.Fix, R.G.Gordon and D.M.Hoffman, J.Am.Chem.Soc. 112 (1990) 7833.

[9] R.Fix, R.G.Gordon and D.M.Hoffman, Chem.Mater. 3 (1991) 1138.

[10] F.Laurent, J.S.Zhao, L.Valade, R.Choukroun and P.Cassoux, J.Anal.appl.Pyrolysis. 24 (1992) 39.

[11] F.Laurent, C.Daures, L.Valade, R.Choukroun, J.P.Legros and P.Cassoux, Mat.Res.Soc.Symp.Proc. 271 (1992) 875.

[12] J.Slifirski, G.Huchet and F.Teyssandier, Proc. of the VIII Euro. Conf. on CVD, Glasgow U.K., Hitchman M.L., Archer N.J. (Eds), Colloque C2 Journal de Physique Supplément N7, (1991) 625.

[13] J.Slifirski, G.Huchet, F.Teyssandier submitted to Chem.Mater.

[14] G.Farges and D.Degout, Thin Solid Films 181 (1989) 365.

[15] C.W.Lee and J.S.Chun, Proc. of the VIII Intern. Conf. on CVD, Paris FRANCE, Wahl G., Blocher J.M., Vuillard G.E. (Eds), (1981) 540.

[16] L.Aggour, E.Fitzer and J.Schlichting, Proc. of the V Intern. Conf. on CVD, Fulmer Grange ENGLAND, Blocher J.M., Hintermann H.E., Hall L.H. (Eds), (1975) 600.

[17] F.Teyssandier, C.Bernard and M.Ducarroir, J.Mater.Sci. 23 (1988) 135. 